\title{
Whales and dolphins (Mammalia, Cetacea) of the Cape Verde Islands, with special reference to the Humpback Whale Megaptera novaeangliae
}

\section{(Borowski, 1781)}

\author{
Cornelis J. Hazevoet ${ }^{1,2}$ \& Frederick W. Wenzel ${ }^{3,4}$ \\ IInstitute for Systematics and Population Biology, University of Amsterdam, P.O. Box 94766, 1090 GT \\ Amsterdam, the Netherlands; ${ }^{2}$ Present address: Museu e Laboratório Zoológico e Antropológico (Museu \\ Bocage), Universidade de Lisboa, Rua da Escola Politécnica 58, 1250-102 Lisboa, Portugal (hazevoet@fc. \\ ul.pt); ${ }^{3}$ Biology Department, Northeastern University, 414 Mugar, Boston, Massachusetts 02115, U.S.A.; \\ ${ }^{4}$ Present address: Northeast Fisheries Science Center, National Marine Fisheries Service, 166 Water Street, \\ Woods Hole, Massachusetts 02543-1026, U.S.A. (frederick.wenzel@noaa.gov)
}

Keywords: Cetacea, Cape Verde Islands, distribution, whaling history

\begin{abstract}
Observations of whales and dolphins in the Cape Verde Islands obtained in 1995 and 1996 are reported and data on the occurrence of 14 taxa are given, including four not previously reported from the region, vizz. Bryde's Whale Balaenoptera edeni, Killer Whale Orcinus orca, Rough-toothed Dolphin Steno bredanensis, and Striped Dolphin Stenella coeruleoalba . An earlier report of Fin Whale $B$, physalus is reviewed and re-identified as $B$. cf. borealis. Status and occurrence of the Humpback Whale Megaptera novaeangliae are discussed at some length. Unpublished observations from other observers are also included and a short account on the history of whaling in the islands is given. $\mathbf{A}$ list of all cetacean taxa reliably recorded in the Cape Verde region is presented and unsubstantiated reports are briefly discussed.
\end{abstract}

\section{Contents}

Abstract

Introduction

Short history of whaling in the Cape Verde Islands

198

Methods

199

Systematic list

200

Discussion

207

Acknowledgements

208

References

209

Appendix 1

211

Appendix 2

211

\section{Introduction}

The Cape Verde Islands (Fig. 1) are an archipelago consisting of 10 islands and several islets situated in the Atlantic Ocean c. $500 \mathrm{~km}$ west of Senegal, West Africa. The total land area is $4033 \mathrm{~km}^{2}$ scattered over $58,000 \mathrm{~km}^{2}$ of ocean. These volcanic islands emerge steeply from depths of about 4000 $\mathrm{m}$. The climate is dry tropical but sea conditions are heavily influenced by the cool Canary current that comes from the north. Consistently strong northeast tradewinds produce rough seas, often making navigation around the islands difficult and hazardous. A former Portuguese colony, the islands gained independence and became the República de Cabo Verde in 1975.

Apart from sparse accounts in the historical whaling literature, little has been written about the Cetacea that occur in Cape Verde seas. During the 19th century, a few specimens of dolphins from the area reached Europe and some of these became the holotypes of nominal taxa (cf. Perrin et al,, 1987). Reiner et al. (1996) presented an overview of cetaceans recorded in the area, based on their own observations as well as published data, and added a list of taxa whose occurrence in the region they considered likely, referring to published records of strandings and offshore occurrences from the West African mainland. Jefferson et al. (1997) reviewed published records of dolphins and porpoises from West Africa, including the Cape Verde Islands.

In this paper, we report on our observations of whales and dolphins in the Cape Verde Islands. The status and occurrence of the Humpback Whale 


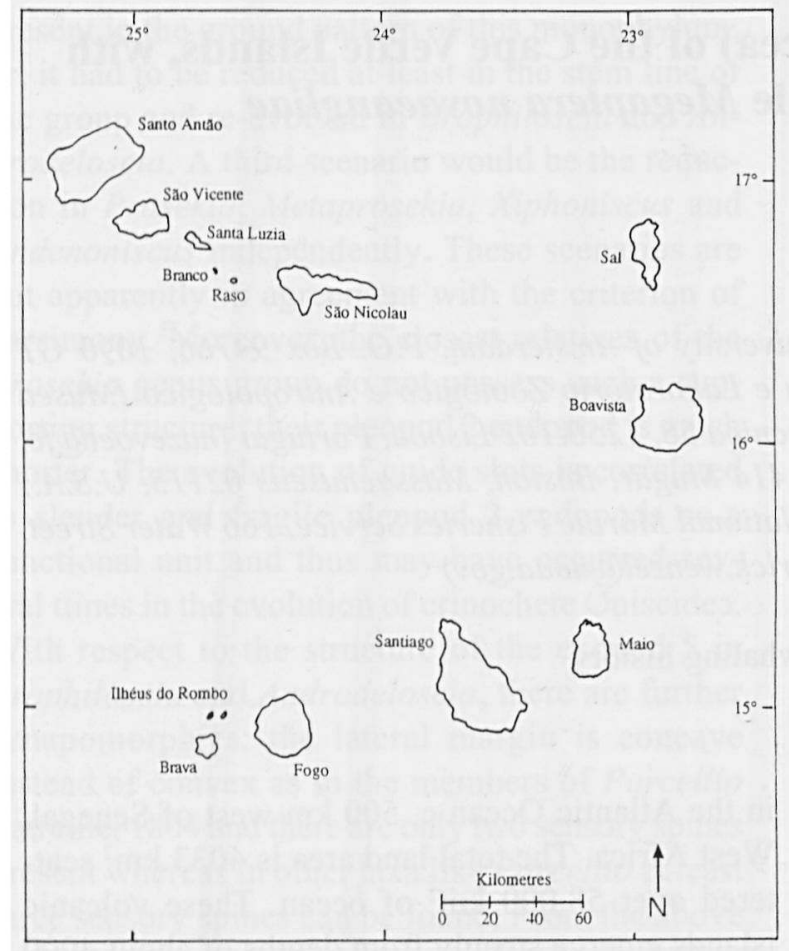

Fig. 1. Map of the Cape Verde Islands.

Megaptera novaeangliae is dealt with in somewhat more detail. A considerable number of additional sightings were obtained from local fishermen but these have been included only when identification proved to be sufficiently reliable. Also included are data from private reports, kindly put at our disposal by other observers, that would easily go unnoticed otherwise. Some corrections to Reiner et al. (1996) and other publications are made. A list of all cetacean taxa reliably recorded in the Cape Verde region - here defined as $14^{\circ} 00^{\prime} \mathrm{N}-18^{\circ} 00^{\prime} \mathrm{N}, 22^{\circ} 00^{\prime} \mathrm{W}$ $26^{\circ} 00^{\prime} \mathrm{W}$ - is presented (Appendix 1) and unsubstantiated reports are briefly discussed (Appendix 2).

\section{Short history of whaling in the Cape Verde islands}

There has been a long tradition of whaling in the Cape Verde Islands. Already during the 16th century, whale products from the islands were exported to Brazil (Ellis, 1969). As elsewhere, whaling during these early years was of a small-scale artisanal nature, probably not seriously affecting populations. From the mid-18th century onwards, European and North American whalers began to frequent these waters on a regular basis. João da Silva Feijo, a Portuguese naturalist who stayed in the islands during the $1780 \mathrm{~s}$, reported that baleias and cachalotes were common, attracting many American, English and French whalers (Carreira, 1986). Early reference works on the Cape Verde Islands invariably remarked on the abundance of whales in these waters (e.g. Chelmicki \& Varnhagen, 1841; Lopes de Lima, 1844).

In the 19th century, New England whalers hunted Humpbacks during the winter months in Cape Verde seas (Kellogg, 1929; Mitchell \& Reeves, 1983). The main hunting area for 'humpbackers' from Provincetown, Massachusetts, was in the West Indies, but "another favorite ground is around the Cape Verde Islands" (Atwood, 1887). Charts in Townsend (1935), mapping 19th century catches by North American whalers, show that Humpback whaling in Cape Verde seas took place in February-May, while another important West African hunting area (Gulf of Guinea) was exploited in JuneSeptember. Townsend's (1935) charts of catches of Sperm Whale Physeter macrocephalus show that in the Cape Verde area this whale was mainly hunted from October to March.

From the late 18 th century, when the first whaling station was established on Brava, considerable quantities of whale oil were also prepared locally. Catching whales from small man-powered boats was a risky business and vivid descriptions of the methods employed and the dangers involved were given by E.J.M. (1864) and Cardoso (1896). In 1874, the Empresa da Pesca da Baleia do Carriçal e do Tarrafal was founded on São Nicolau and in 1883 a similar enterprise was undertaken on Sal (Cardoso, 1896; Carreira, 1983). By that time, however, whale populations had already been severely depleted and towards the end of the 19 th century foreign whalers began to abandon their activities in Cape Verde seas. Friedlaender (1913), who stayed in the islands for five months in 1912, wrote that there still existed whaling stations on São Nicolau and Maio but that operations had all but ceased due to the scarcity of whales. In 1914, when whales had been almost exterminated in these waters, the Portuguese 
colonial government issued a decree in which the capture of immature animals was forbidden and the maximum yearly catch set at 6,000 (Carreira, 1983). This measure, however, came too late to generate an increase of the populations and, in view of the catch size still allowed, probably even had the opposite effect.

Today, dolphins can be found quite regularly in the markets, especially on Santiago, and stranded or weakened offshore whales are readily butchered by the local population despite existing legislation that provides full protection for all cetaceans (Law 17/1987). As with other environmental legislation, there is little or no interest among the local authorities to enforce such laws and consequently the degradation of Capeverdian wildlife, both marine and terrestrial, continues at an alarming rate. The Republic of Cape Verde is not a member of CITES, although discussions about the country joining the convention have been going on for the past 10 years or more.

\section{Methods}

Payne \& Katona (1986) wrote that they knew of "three groups of scientists who have visited the Cape Verdes [in recent years] to look for Humpbacks but no whales have been seen". In order to improve this situation, one of the authors (FWW) undertook preliminary surveys in the years 19901991, the results of which were included in Reiner et al. (1996). In February-April 1995 and February-May 1996, our team (see acknowledgements) conducted dedicated surveys around the southern parts of the island of Sal (Fig. 2) to establish the size and composition of the Humpback population. An important feature of this island is a shallow bay in the southwest (Baía da Mordeira) which may conceivably serve as a Humpback calving area.

Our field work (hereafter referred to as 'Humpback survey') was conducted at sea in a $4.5-\mathrm{m}$ inflatable boat as well as from elevated positions on land. Due to the prevailing strong winds in the Cape Verdes at this time of year, adverse weather conditions often prevented work at sea. Beach surveys to search for stranded marine mammals were conducted for $70 \%$ of Sal island. The remain-

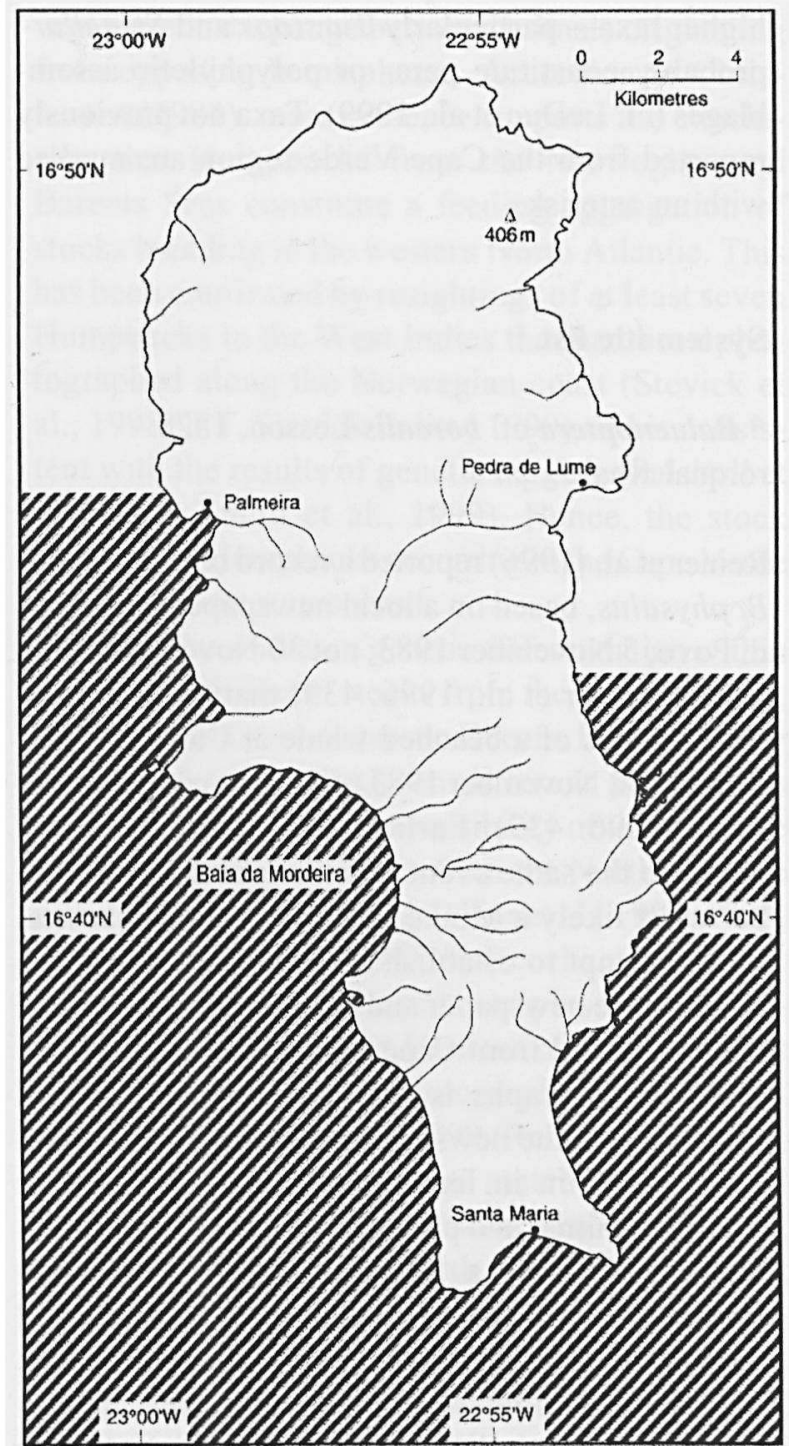

Fig. 2. Map of the island of Sal. The area surveyed in FebruaryApril 1995 and February-May 1996 ('Humpback survey') is indicated by hatching.

ing 30\% of Sal's shore consists of volcanic rock and cliffs with no beach front or intertidal. In 1996, a number of trips were undertaken to the island of Boavista aboard a larger vessel, enabling us to expand the search for Cetacea beyond our usual range. All Cetacea encountered during the surveys were noted. Unless stated otherwise, general data on world-wide status and distribution in the following are taken from Jefferson et al. (1993). For the sake of convenience, nomenclature follows current usage although we are aware that some 
higher taxa - particularly Tursiops and Stenellaprobably constitute para- or polyphyletic assemblages (cf. LeDuc et al., 1999). Taxa not previously reported from the Cape Verde region are marked with an asterisk.

\section{Systematic list}

* Balaenoptera cf. borealis Lesson, 1828 rorqual whale

Reiner et al. (1996) reported a record of a Fin Whale B. physalus, based on a local newspaper item ( Voz di Povo, 5 November 1983; not 30 November 1993, contra Reiner et al., 1996: 439) that included two photographs of a beached whale at Cidade Velha, Santiago, 2 November 1983 (not 1993, contra Reiner et al., 1996: 439). Earlier, Lagendijk (1984) referred to the same event and thought the animal to be "most likely a Minke Whale" B. acutorostrata. In an attempt to establish the animal's taxonomic identity, the newspaper and photographs concerned were retrieved from Cape Verde archives and one of the photographs is reproduced here (Fig. 3). According to the newspaper report the whale measured c. $4.5 \mathrm{~m}$ in length, indicating a young or newborn animal and presumably excluding $B$. physalus, which has a length of 6-6.5 $\mathrm{m}$ at birth (Jefferson et al., 1993). As far as can be discerned from the photographs, the animal's ventral side is largely darkly coloured, this being another indication of it not being $B$. physalus, in which the funderparts are whitish. The head does not appear to be markedly V-shaped as in $B$. acutorostrata but seems rather rounded. The left pectoral flipper appears to be chopped off and consequently the presence of a white band - typical of $B$. acutorostrata - cannot be verified. Colouration and head shape suggest either Sei Whale B. borealis or Bryde's Whale $B$. edeni. Mostly white baleen bristles - as in the Sei Whale - are apparent, the baleen plates themselves being largely hidden by the bristles. The dome-shaped rostrum with a fairly strong curvature of the maxillaries distinguishes the Sei Whale from the Bryde's Whale. The almost homogeneous grey colouration of the throat and lips are also indicative of the Sei Whale. Al- though variable, Bryde's Whales often have dark lips contrasting with a white throat. In view of these features, we provisionally identify the animal as a Sei Whale, a taxon which has not been reported previously from the Cape Verde region. However, on the basis of the photographs alone, Bryde's Whale cannot be excluded with certainty. Reiner et al. (1996) claimed the animal to be a male, but the photographs do not provide evidence for this and neither was the sex hinted at in the newspaper report. The Sei Whale is distributed world-wide in temporate waters and seems to enter tropical seas more often than the Fin Whale. Due to the difficulty of distinguishing Sei and Bryde's Whales, the tropical distribution of the former is poorly known.

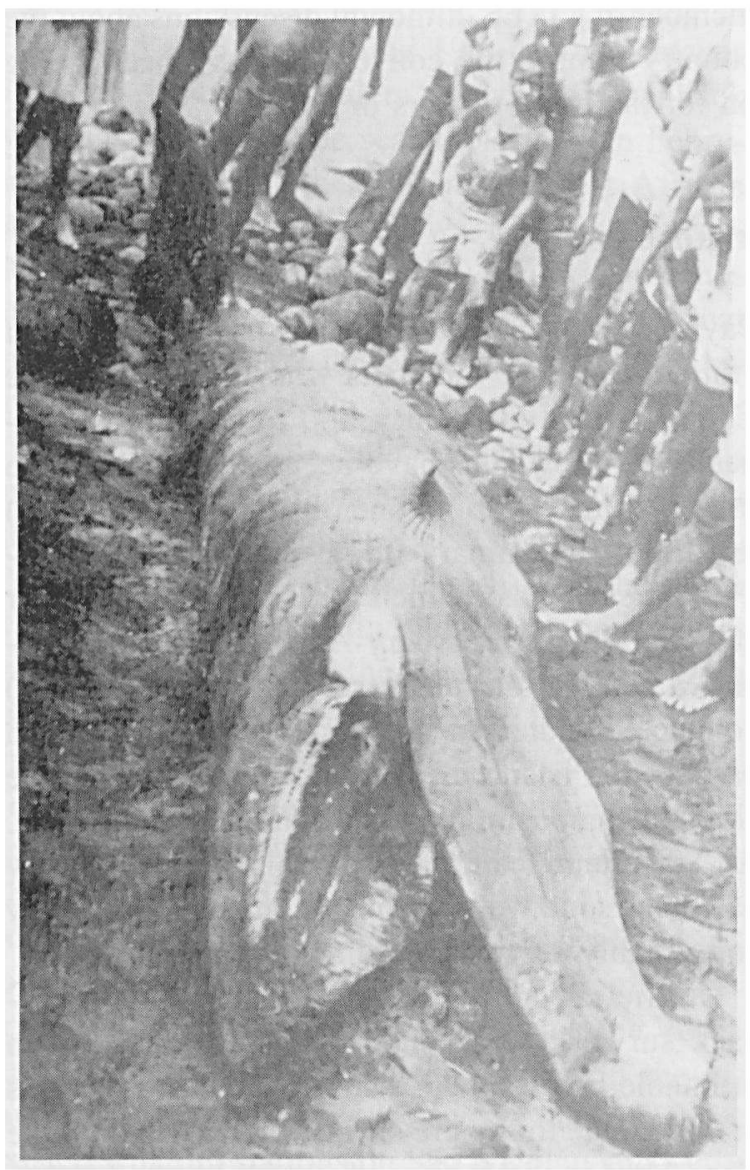

Fig. 3. Juvenile rorqual whale Balaenoptera $\mathrm{cf}$. borealis brought ashore by fishermen, Cidade Velha, Santiago, Cape Verde Islands, 2 November 1983 (photo originally published in Voz di Povo, Ano IX, No. 358, 5 November 1983). 


\section{* Balaenoptera edeni Anderson, 18791,2 - Bryde's Whale}

Occurs world-wide in tropical and subtropical waters, often near shore in areas of high productivity. Referring to a record from Senegal, Reiner et al. (1996) listed Bryde's Whale as likely to occur in the archipelago and this can now be confirmed. A cow and calf were seen off Tarrafal, São Nicolau, 28 September $1988(\mathrm{CJH})$. Close views could be obtained and the three characteristic ridges on the anterior part of the adult's head were seen. In addition, a freshly stranded calf was found on the beach c. $8 \mathrm{~km}$ south of Sal Rei, Boavista, 29 February 1996 (Humpback survey).

\section{Megaptera novaeangliae (Borowski, 1781) - Humpback Whale}

The Humpback Whale is distributed world-wide, migrating from the tropics (breeding areas) to polar or subpolar seas (feeding areas). Historically, North Atlantic Humpback Whales wintered in the Caribbean and around the Cape Verde Islands (Townsend, 1935; Mitchell \& Reeves, 1983; Bannister et al., 1984; Winn \& Reichley, 1985). The total North Atlantic population has recently been estimated at c. 10,500 (Smith et al, 1999). This is substantially larger than estimates made in the 1980s (cf. Katona \& Beard, 1990) but it is unclear whether this indicates a genuine population growth or simply reflects improved methods of estimation.

Monthly distribution maps based on data collected during the 1950s show an increase of Humpback sightings off West Africa between $20^{\circ} \mathrm{N}$ and $20^{\circ} \mathrm{S}$ in March-May and September-October (Slijper et al., 1964). These authors suggested that animals seen in spring may belong to northern populations while those present in autumn may be of southern origin. This would imply that, although there is spatial overlap between northern and southern stocks at these latitudes, temporal separation would pre-

\footnotetext{
'The date of Anderson's description is usually, but incorrectly, cited as 1878 (cf. Rice, 1998).

2 The taxonomic status of "Bryde's Whale" is complex and, as currently defined, probably includes two or more diagnosably distinct taxa (cf. Baker \& Palumbi, 1997; Rice, 1998).
}

vent genetic exchange between animals originating from opposing hemispheres. According to Christensen (1984), most evidence supports the conclusion that Humpbacks from the Norwegian and Barents Seas constitute a feeding aggregation of stocks breeding in the western North Atlantic. This has been confirmed by resightings of at least seven Humpbacks in the West Indies that had been photographed along the Norwegian coast (Stevick et al., 1998; P.T. Stevick in litt., 1999) and is consistent with the results of genetic tagging (Palsbøll et al., 1997; Smith et al., 1999). Hence, the stock affinities of Humpbacks occurring in the Cape Verde region remain unresolved.

Molecular studies of genetic differentiation within and among different stocks from the North Pacific, North Atlantic and Antarctic Oceans found a highly structured pattern between different populations but could not exclude the possibility of limited gene flow between Humpbacks from the North Atlantic and Antarctic Oceans (e.g. Baker et al., 1990, 1993, 1994; Palsbøll et al., 1997; Valsecchi et al., 1997). These studies did not include samples from Humpbacks wintering in Cape Verdean or adjacent West African waters. Fluke photographs $(n=24)$ obtained in 1991, 1995 and 1999 (Reiner et al., 1996; Carrillo et al., 1999) have not matched any animal in the North Atlantic Humpback Whale Catalogue, nor in the Years of the North Atlantic Humpback (YONAH) catalogue, which together hold $10,000+$ photographs of flukes. This in itself is perhaps an indication that a distinct eastern Atlantic stock, wintering off West Africa, still exists, because the catalogued photographs almost exclusively stem from the western Atlantic. In order to shed further light on the geographical origin of the animals wintering in the Cape Verde region, additional fluke photographs, sound recordings and sloughed-skinbiopsies will need to be collected during future Cape Verde Humpback surveys.

Recent observations of Humpbacks in the Cape Verde region can be summarized as follows. In 1979, Winn et al. (1981) obtained 13 song sequences (presumably from a single individual) in the Cape Verdes and found these to be essentially equivalent to songs from the West Indies, suggesting that exchange between these two breeding grounds may occur. During a three-week cruise in the archipelago 
Table I. Observations of Humpback Whale Megaptera novaeangliae.

\begin{tabular}{|c|c|c|c|c|}
\hline Date & Number & Location & - Source & \\
\hline 20 February 1995 & 1 (singer) & W. of Palmeira, Sal & Humpback survey & \\
\hline 8 March 1995 & 1 (singer) & W. of Palmeira, Sal & Humpback survey & \\
\hline 10 March 1995 & 3 (incl. cow \& calf) & Porto Novo, Santo Antão & W. Williams & \\
\hline 18 March 1995 & 1 & off western Sal & fishermen & \\
\hline 20 March 1995 & 1 (singer) & $1 \mathrm{~km} \mathrm{~S}$. of Santa Maria, Sal & Humpback survey & \\
\hline 22 March 1995 & 1 & off Palmeira, Sal & Humpback survey & \\
\hline 23 March 1995 & 2 (cow \& calf) & Baía da Mordeira, Sal & Humpback survey & \\
\hline 24 March 1995 & $2(\operatorname{cow} \&$ calf) & Baia da Mordeira, Sal & Humpback survey & \\
\hline 25 March 1995 & 1 & off Palmeira, Sal & Humpback survey & \\
\hline 30 March 1995 & 1 (singer) & off W.S.W. Sal & Humpback survey & \\
\hline 31 March 1995 & 1 (singer) & W. of Santa Maria, Sal & Humpback survey & \\
\hline 13 April 1995 & 2 (cow \& calf) & off Santa Maria, Sal & windsurfer & \\
\hline 10 March 1996 & 2 (cow \& calf) & off Palmeira, Sal & fishermen & \\
\hline 19 March 1996 & 2 (cow \& calf) & off Palmeira, Sal & fishermen & \\
\hline 24 March 1996 & 3 & off N.W. Boavista & fishermen & \\
\hline 30 March 1996 & 1 & $2 \mathrm{~km} \mathrm{~S}$. of Santa Maria, Sal & fishermen & \\
\hline 9 April 1996 & 2 & off Santa Maria, Sal & Humpback survey & \\
\hline 10 April 1996 & 2 & off Santa Maria, Sal & Humpback survey & \\
\hline 11 April 1996 & 1 & off Sal Rei, Boavista & J. Soares & \\
\hline 16 April 1996 & 2 & eastcoast of Sal & fishermen & \\
\hline 16 April 1996 & 1 (singer) & N. of Sal Rei, Boavista & fishermen & \\
\hline 17 April 1996 & 2 (cow \& calf) & Baía da Mordeira, Sal & Humpback survey & \\
\hline 19 April 1996 & 1 & off Palmeira, Sal & fishermen & \\
\hline 20 April 1996 & 2 & E. of Santa Maria, Sal & Humpback survey & \\
\hline 20 April 1996 & 5-6 (incl. cow \& calf) & N.W. of Sal Rei, Boavista & Humpback survey & . \\
\hline 22 April 1996 & 2 (breaching) & $5 \mathrm{~km}$ E. of Santa Maria, Sal & Humpback survey & \\
\hline 22 April 1996 & 2 & $5 \mathrm{~km} \mathrm{~N}$. of Sal Rei, Boavista & J. Soares & \\
\hline 12 May 1996 & 1 (singer) & $4 \mathrm{~km}$ S.E. of Santa Maria, Sal & Humpback survey & \\
\hline
\end{tabular}

in March-April 1984, Lagendijk (1984) sighted only a single Humpback. The preliminary 1990-1991 surveys yielded a total of six observations, while several more were reported by fishermen and other sea-going people. An additional two sightings as well as a number of strandings were reported by Reiner et al. (1996). In 1995 and 1996, our observations of Humpback Whales around the islands of Sal and Boavista numbered 12 and 16, respectively, including reports by local observers (Table I; Fig. 4). Only two of these Humpback sightings related to a cow and newborn calf in a shallow (< $15 \mathrm{~m}$ ) protected area (Baía da Mordeira, 23-24 March 1995 and 17 April 1996), although other cows with calves were observed not far from there off Palmeira. Interestingly, airplane pilots who often fly low over Baía da Mordeira before landing at Sal airport, informed us that they "quite regularly observed Humpbacks" there at this time of year. The pilots identified Humpbacks by their long

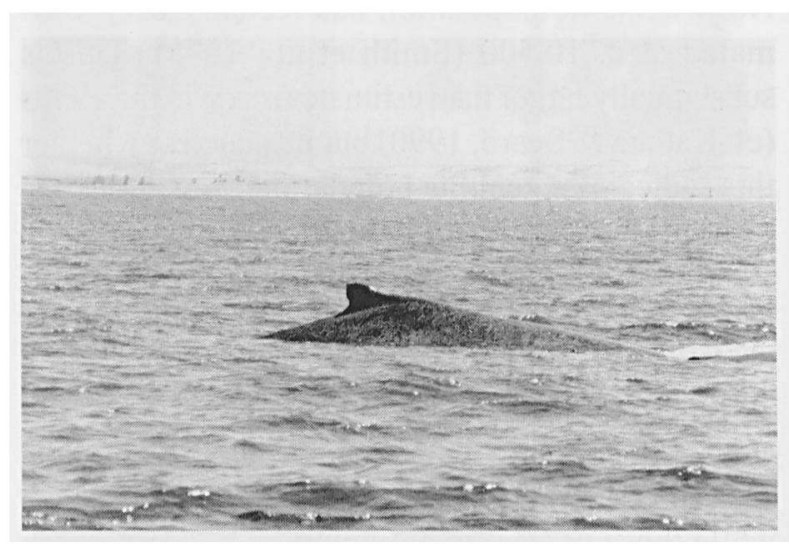

Fig. 4. Humpback Whale Megaptera novaeangliae, Baia da Mordeira, Sal, Cape Verde Islands, 23 March 1995 (photo by F.W. Wenzel).

whitish flippers being clearly visible in the blue water.

Because it is possible that on different occasions the same animal(s) were encountered, it is diffi- 
cult to give an estimate of the number of individuals sighted during the surveys. Nevertheless and given that the total eastern North Atlantic stock has been estimated at c. 100 animals (Winn \& Reichley, 1985), it can be concluded that the Cape Verde region still constitutes an important breeding area, even though numbers today may constitute only a pale shadow of those in the past.

\section{Physeter macrocephalus Linnaeus, 1758 - Sperm Whale}

Sperm Whales are widely distributed in the oceans around the world. Reiner et al. (1996) mentioned three strandings and six sightings. These authors stated that they "found no previous record, including the historical whaling literature". This is surprising because Townsend (1935), to which Reiner et al. (1996) referred elsewhere in their paper, mapped a large number of Sperm Whale catches in the Cape Verde region based on 19th-century logbooks of American whaleships. Indeed, apart from Humpbacks, Sperm Whales were the main target for whalers in these seas and cachalotes are often mentioned as an important resource in the 18thand 19th-century literature on the islands (e.g. Chelmicki \& Varnhagen, 1841; Lopes dé Lima, 1844; Fournier, 1847; J. da Silva Feijó in Carreira, 1983). No Sperm Whales were observed in 19951996 , but there is a recent sighting of at least 11 very active and tail-slapping individuals at about two thirds of the way from Fogo to Santo Antão (approx. $16^{\circ} 20^{\prime} \mathrm{N}, 25^{\circ} 00^{\prime} \mathrm{W}$ ), with one individual breaching clear of the water seven times in succession, 18 January 1989 (K.M. Morgan).

\section{* Orcinus orca (Linnaeus, 1758) - Killer Whale}

Killer Whales are distributed world-wide but are more common in cold-temperate to subpolar waters. There are many records from West Africa (summarized by Jefferson et al., 1997) as well as a sighting at $19^{\circ} 01^{\prime} \mathrm{N}, 19^{\circ} 41^{\prime} \mathrm{W}$ (northeast of the Cape Verdes), 18 April 1816 (Reeves \& Mitchell, 1988). In view of this evidence, Reiner et al.(1996) listed the Killer Whale as likely to occur in the region. We report the sighting of a herd of nine animals, 4-5 km south of Santa Maria, Sal, 29 February 1996 (Humpback survey), which appears to be the first documented record from Cape Verde seas.

Grampus griseus (G. Cuvier, 1812) - Risso's Dolphin

A cosmopolitan tropical and warm temperate taxon of which Reiner et al. (1996) reported a single observation for the region, viz. c. 20 animals off eastern Santo Antão, 26 June 1993. We add a sighting of at least three animals in the lee of Raso islet (at the same time as a group of Steno bredanensis, see below), 25 January 1989 (K.M. Morgan). The specimen listed as being collected in the Cape Verde Islands by Broekema (1983) was actually obtained in the Azores (cf. Reiner et al., 1996).

Globicephala melas (Traill, 1809) - Long-finned Pilot Whale

The Long-finned Pilot Whale is the temperate to subpolar counterpart of the Short-finned Pilot Whale. There are a few records from West Africa (summarized by Jefferson et al., 1997) and two reports from the Cape Verde region (Lagendijk, 1984), although no details were given as to how the latter were distinguished from G. macrorhynchus. On 3 March 1995, the stranded remains of 5-8 pilot whales, including one large male and one calf - all in an advanced state of decay - were found along Baía da Mordeira, Sal (Humpback survey). These were identified as $G$. melas on the basis of their cranial morphology (5-7 partial skulls, 5 right mandibles, 1 left mandible; specimens not preserved), notably the more elongated rostrum compared to G. macrorhynchus. The extent of distributional overlap between Long-finned and Shortfinned Pilot Whale in the northeastern Atlantic was discussed by Nores \& Pérez (1988), who concluded that the former may range south to Mauritania while the latter regularly occurs as far north as the Bay of Biscay. 

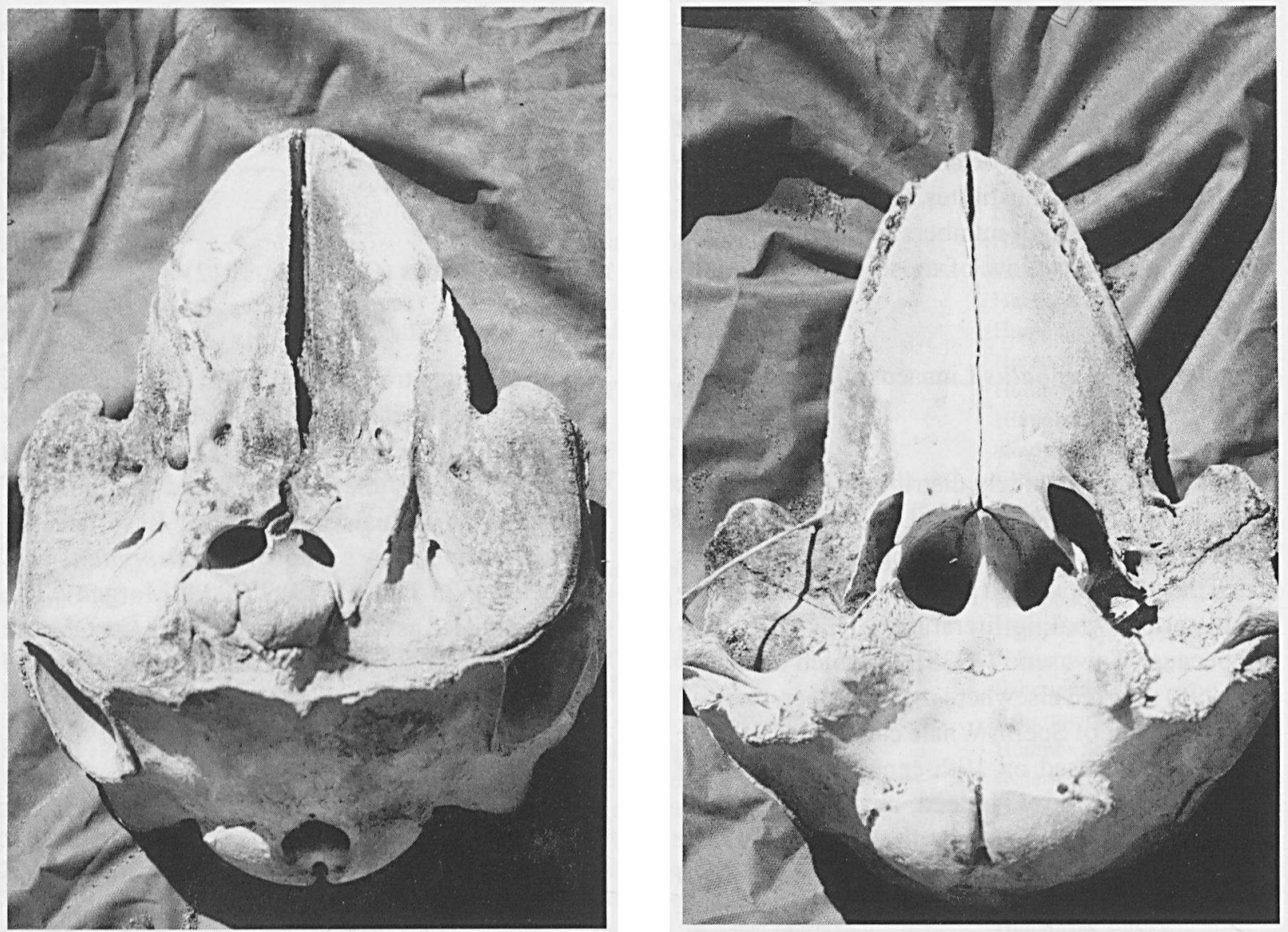

Fig. 5. Dorsal (A) and ventral view (B) of skull of stranded Short-finned Pilot Whale Globicephala macrorhynchus, Sal, Cape Verde Islands, March 1996 (photos by F.W. Wenzel).

Table II. Observations of Short-finned Pilot Whale Globicephala macrorhynchus. Observations marked* refer to unidentified Globicephala sp.

\begin{tabular}{|c|c|c|c|}
\hline Date & Number & focation & Source \\
\hline 1 February 1985 & c. 12 & between Cima and Fogo & S.C. Madge \\
\hline 14 January 1986 & $>10^{*}$ & $16^{\circ} 41^{\prime} \mathrm{N}, 24^{\circ} 52^{\prime} \mathrm{W}$ & C.J. Camphuysen \\
\hline 29 February 1996 & $12-15$ & 6-7 km S. of Santa Maria, Sal & Humpback survey \\
\hline 5 March 1996 & 15 & 3-4 km S. of Santa Maria, Sal & Humpback survey \\
\hline 17 March 1996 & 2 & $1 \mathrm{~km} \mathrm{S.} \mathrm{of} \mathrm{Santa} \mathrm{Maria,} \mathrm{Sal}$ & Humpback survey \\
\hline 18 March 1996 & $22-30$ & $2 \mathrm{~km} \mathrm{~S}$. of Santa Maria, Sal & Humpback survey \\
\hline 11 April 1996 & $20^{*}$ & $5 \mathrm{~km} \mathrm{~S}$. of Santa Maria, Sal & J. Soares \\
\hline 13 April 1996 & $40-50^{*}$ & $5 \mathrm{~km}$ E. of Santa Maria, Sal & fishermen \\
\hline 21 April 1996 & $20-25$ & $6 \mathrm{~km} \mathrm{S.} \mathrm{of} \mathrm{Santa} \mathrm{Maria,} \mathrm{Sal}$ & Humpback survey \\
\hline
\end{tabular}

Globicephala macrorhynchus Gray, 1846 - Shortfinned Pilot Whale

Widespread in tropical to warm temperate seas in oceanic to coastal waters, the Short-finned Pilot Whale has been reported from the Cape Verde region on three previous occasions (cf. Lagendijk, 1984; Reiner et al., 1996). Hundreds of vertebrae, ribs and a number of skulls, strewn over kilometres of beach, were found along the shore c. $8 \mathrm{~km}$ south of Pedra de Lume, Sal, in March 1995. Local fishermen reported that as many as 150 pilot whales 


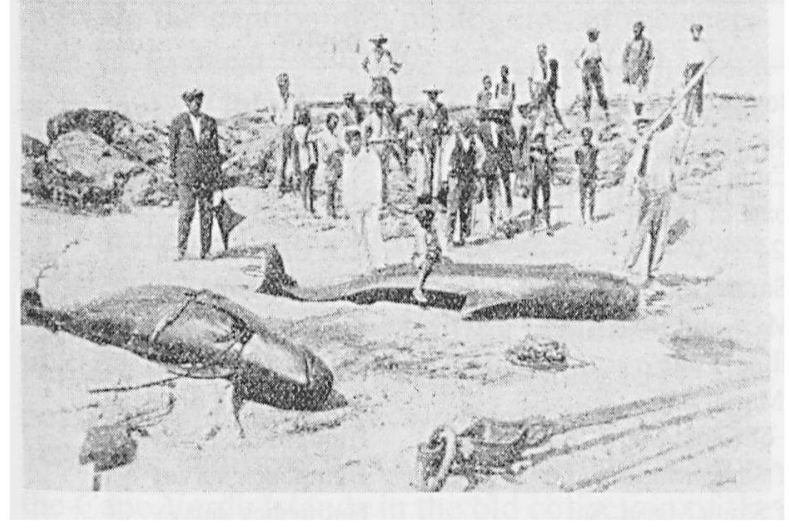

Fig. 6. Beached Short-finned Pilot Whales Globicephala macrorhynchus, Maio, Cape Verde Islands, probably late 1920s (photo reproduced from Boletim da Agência Geral das Colónias, 45: 213, 1929).

came ashore there in 1972 and that another group (10-30) beached in 1990. According to a local informant, 3-4 Globicephala sp. were stranded on Curralinho beach, Boavista, in September or October 1995. In March 1996, a skeleton was found along the shore c. $8 \mathrm{~km}$ northeast of Santa Maria, Sal (Fig. 5; specimen not preserved). It was locally reported that this animal had stranded in mid December 1995.

A photograph taken on the island of Maio at some time during the late 1920 s, published in Lopes (1929), shows two beached Short-finned Pilot Whales (Fig. 6). The original caption reads (translated from the Portuguese):

"Island of Maio - Two examples of the 'Black Fish' (Globicephalus sp.). These fishes [sic], which can attain a weight of 400 kilograms, become stranded on the coasts of this island at certain times of the year. At dawn, they are thrown on the sand in groups of 40 to 50 . Their meat, when salted and kept in barrels, is a true delicacy befallen to the island because it guarantees the alimentation of its inhabitants throughout the year. It is said that it is exactly during the years of greatest misery that they appear in the largest numbers."

In the accompanying article, no reference is made to the photograph, nor is there any further mentioning of Cetacea. Recent observations at sea, including records of unidentified Globicephala sp., are given in Table II. Despite the paucity of earlier reports, the number of recent records leads us to conclude that Short-finned Pilot Whale is common in the region.

* Steno bredanensis (G. Cuvier in Lesson, 1828) Rough-toothed Dolphin

Occurs world-wide in tropical and subtropical seas but seems to be nowhere numerous. Referring to records from Senegal and Mauritania, Reiner et al. (1996) mentioned Rough-toothed Dolphin as likely to occur in Cape Verdean seas and this is confirmed by recent observations. Apart from three sightings obtained in the Sal-Boavista area in 1996, two earlier records have come to our attention (Table III). The source of a record just south of the Cape Verde Islands mapped by Miyazaki \& Perrin (1994) is unclear and possibly stems from a confusion with Cap Vert, Senegal (W.F. Perrin in litt., 1999).

\section{Delphinus spp. - common dolphin}

Common dolphins are distributed world-wide in tropical to warm temperate seas. Reiner et al. (1996) listed seven observations of Delphinus spp. and Lagendijk (1984) reported a single sighting of common dolphins. In view of the recent taxonomic revision of Delphinus (cf. Heyning \& Perrin, 1994; Rosel et al., 1994), Reiner et al. (1996) refrained

Table III. Observations of Rough-toothed Dolphin Steno bredanensis.

\begin{tabular}{llll}
\hline Date & Number & Location & Source \\
\hline 16 January 1989 & $7-8$ & off S.W. Santiago & K.M. Morgan \\
25 January 1989 & $7+$ & off S. Raso & K.M. Morgan \\
21 March 1996 & $6-8$ & $2 \mathrm{~km}$.S. of Santa Maria, Sal & Humpback survey \\
28 March 1996 & $10-15$ & $10 \mathrm{~km} \mathrm{~N}$. of Sal Rei, Boavista & Humpback survey \\
21 April 1996 & $12-18$ & $4 \mathrm{~km} \mathrm{~N}$ of Sal Rei, Boavista & Humpback survey \\
\hline
\end{tabular}


Table IV. Observations of Bottlenose Dolphin Tursiops truncatus.

\begin{tabular}{|c|c|c|c|}
\hline Date & Number & Location & Source \\
\hline 6 February 1985 & c. 12 & S.W. of Boavista & S.C. Madge \\
\hline 8 February 1985 & c. 10 & between São Nicolau and Raso & S.C. Madge \\
\hline 9 February 1985 & c. 25 & between Cima and Fogo & S.C. Madge \\
\hline 13 February 1985 & c. 10 & off east coast of Brava & S.C. Madge \\
\hline 14 January 1986 & c. 20 & $16^{\circ} 36^{\prime} \mathrm{N}, 24^{\circ} 30^{\prime} \mathrm{W}$ & C.J. Camphuysen \\
\hline 6 March 1986 & c. 10 & off S.W. Santiago & C.J. Hazevoet \\
\hline 12 January 1989 & $15+$ & between Maio and Boavista & K.M. Morgan \\
\hline 5 June 1989 & c. 25 & off São Filipe, Fogo & C.J. Hazevoet \\
\hline 21-22 March 1995 & c. 50 & off Santa Maria, Sal & tourists/Dive Shop \\
\hline 6 March 1996 & $40-50$ & 5-6 km E. of Santa Maria, Sal & Humpback survey \\
\hline 21 March 1996 & $40-50$ & $2 \mathrm{~km}$ S. of Santa Maria, Sal & Humpback survey \\
\hline 22 March 1996 & $20-25$ & $3 \mathrm{~km} \mathrm{S.} \mathrm{of} \mathrm{Santa} \mathrm{Maria,} \mathrm{Sal}$ & Humpback survey \\
\hline 23 March 1996 & $20-25$ & $3 \mathrm{~km} \mathrm{~S}$. of Santa Maria, Sal & Humpback survey \\
\hline 21 April 1996 & $4-7$ & $6 \mathrm{~km} \mathrm{S.} \mathrm{of} \mathrm{Santa} \mathrm{Maria,} \mathrm{Sal}$ & Humpback survey \\
\hline 22 April 1996 & $20-30$ & $4 \mathrm{~km}$ E.S.E. of Santa Maria, Sal & Humpback survey \\
\hline 30 January 1999 & $20+$ & off west coast of São Nicolau & M. Nunes \& C. Santos \\
\hline
\end{tabular}

from assigning these sightings to either Shortbeaked Common Dolphin D. delphis Linnaeus, 1758, or Long-beaked Common Dolphin D. $\mathrm{ca}$ pensis Gray, 1828, because both taxa may occur in the region and these would be difficult to separate during observations at sea. One more sighting has come to our attention: seven common dolphins seen at $17^{\circ} 17^{\prime} \mathrm{N}, 24^{\circ} 34^{\prime} \mathrm{W}$ (north of Santa Luzia), 12 January 1986 (C.J. Camphuysen), were reported to be $D$. delphis but the possibility of $D$. capensis again cannot be excluded. Reiner et al. (1996) claimed that Delphinus is "the most abundant cetacean in the Cape Verdes". However, given the number of Globicephala and Tursiops observations (cf. Tables II and IV) and the few records of $D \& l$ phinus reported during the last decade, it may be questioned whether this is indeed the case.

\section{Tursiops truncatus (Montagu, 1821) - Bottlenose Dolphin}

With a world-wide distribution in mainly coastal tropical and temperate seas, the Bottlenose Dolphin is among the commonest cetaceans in the archipelago. Reiner et al. (1996) listed 13 records and earlier Lagendijk (1984) reported two sightings. To these, another 15 observations can now be added (Table IV; Fig. 7).

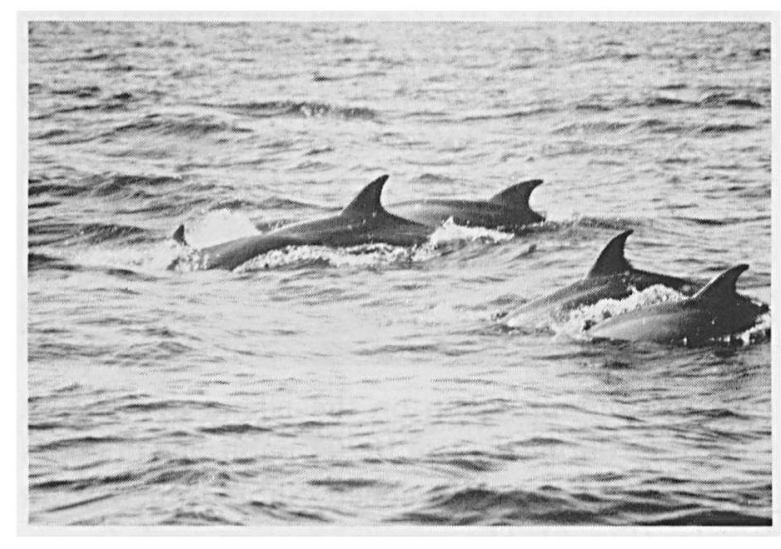

Fig. 7. Bottlenose Dolphins Tursiops truncatus, off Santa Maria, Sal, Cape Verde Islands, 22 March 1996 (photo by D. Holcer).

\section{Stenella attenuata (Gray, 1846) - Pantropical Spotted Dolphin}

The Pantropical Spotted Dolphin occurs world-wide throughout tropical and subtropical oceans (Perrin et al., 1987). One (not two; contra Reiner et al., 1996) was collected at $16^{\circ} 40^{\prime} \mathrm{N}, 21^{\circ} 00^{\prime} \mathrm{W}$, just east of the study area, during the mid-19th century. It was described and named Clymene punctata by Gray (1866) - a junior synonym of S. attenuata and considered the only record for the region by Reiner et al. (1996). However, Cadenat (1959) reported a 'spotted dolphin' obtained in Praia, Santiago, provisionally identified as Clymene 
punctatus in his text but referred to as Stenella indet. in the caption of a photograph of the specimen (cf. Cadenat 1959: 1393 \& Plate XVIII), which is in fact of the present taxon (cf. Perrin et al,, 1987). This animal was collected in June 1950 (given as 1951 by Cadenat, 1959) and the skull is kept in the collection of the Zoölogisch Museum, Amsterdam (see Appendix 1). A dolphin captured between Boavista and Maio by Antoine Joseph Pernety in 1763 or 1764 (cf. van Bree, 1971) was possibly referable to $S$. attenuata (Perrin et al., 1987). In addition, two Stenella specimens from the Cape Verde Islands in the old collection of the Museu Bocage, Lisbon (destroyed by fire in 1978), may have been either $S$. attenuata or S. frontalis (Hazevoet, 1999).

We report the following recent observations: $4+$ in the lee of Sal at dusk, 26 January 1989 (K.M. Morgan) and 6-8 animals c. $3 \mathrm{~km}$ south of Santa Maria, Sal, 22 March 1996 (Humpback survey).

Stenella frontalis (G. Cuvier, 1829) - Atlantic Spotted Dolphin

This is an endemic taxon of the tropical to warmtemperate Atlantic Ocean (Perrin et al., 1987). There are two old records from Cape Verde seas. One concerns the holotype of Delphinus frontalis $\mathrm{G}$. Cuvier, 1829, while the other is the holotype of Delphinus froenatus F. Cuvier, 1829, the latter being a junior synonym of the former (cf. Perrin et al., 1987; Appendix 1). Lagendijk (1984) and Reiner et al. (1996) both reported a single sighting, to which we can add the following observations: $20-50$ close inshore off the western coast of Fogo, 13 February 1985 (S.C. Madge), c. 20 off western São Nicolau, 23 February $1991(\mathrm{CJH})$, and c. 15 west of São Nicolau, 30 January 1999 (M. Nunes \& C. Santos). Caution is needed with all of these records because identification of spotted dolphins at sea is notoriously difficult and the possibility of confusion with $S$. attenuata cannot be ruled out completely.
* Stenella coeruleoalba (Meyen, 1833) - Striped
Dolphin

The Striped Dolphin is distributed world-wide in temporate, subtropical, and tropical seas but there is only a relatively small number of records from West Africa (cf. Jefferson et al., 1997). The taxon was not mentioned by Reiner et al. (1996), neither as confirmed nor as potentially occurring in the Cape Verde region. Here we report the sighting of at least 15 Striped Dolphins off the western coast of Fogo, 10 February 1999 (M. Nunes \& C. Santos). Identification was based on the two black stripes extending from the eye to the anus and flippers, the grey backs with large stripes of light grey on the sides, and the pale belly.

A record at $18^{\circ} 00^{\prime} \mathrm{N}, 24^{\circ} 00^{\prime} \mathrm{W}$ (Wilson et al., 1987; Perrin et al., 1994) probably stems from a mixing up of data and likely represents the same as that just north of Cap Vert, Senegal, the latter being based on a specimen in the Muséum national d'Histoire naturelle, Paris, from that location (W.F. Perrin in litt., 1999). The reference for the record north of the Cape Verde Islands given by Wilson et al. (1987) is an error (W.F. Perrin in litt., 1999).

Stenella longirostris (Gray, 1828) - Spinner Dolphin

Spinner dolphins occur throughout the tropical and subtropical oceans. Reiner et al. (1996) reported three sightings from the Cape Verde region. To this "we add the sighting of 25-30 animals, $5-6 \mathrm{~km}$ south of Santa Maria, Sal, 29 February 1996 (Humpback survey). These could be distinguished from S. clymene (Gray, 1846) by their distinctively long beaks (cf. Perrin et al., 1981).

\section{Discussion}

Apart from those discussed above, there are confirmed records of three more taxa from the Cape Verde region, viz. Blue Whale Balaenoptera musculus (Linnaeus, 1758), Cuvier's Beaked Whale Ziphius cavirostris G. Cuvier, 1823, and Melonheaded Whale Peponocephala electra (Gray, 1846) 
(see Appendix 1). Klinowska (1991), referring to Kirpichnikov (1950), claimed the existence of "an East Atlantic stock [of Blue Whale] wintering at the Cape Verde Islands". However, Kirpichnikov (1950) only reported a few sightings between the Cape Verde Islands and the African mainland and there is nothing in his text justifying Klinowska's (1991) assertion.

Based on published records from Mauritania, Senegal, and Guinea-Bissau, Reiner et al. (1996) suggested the Northern Right Whale Eubalaena glacialis (Müller, 1776), Pygmy Sperm Whale Kogia breviceps (De Blainville, 1838), Gervais" Beaked Whale Mesoplodon europaeus Gervais, 1855 , Pygmy Killer Whale Feresa attenuata Gray, 1874, Atlantic Hump-backed Dolphin Sousa teuszii (Kükenthal, 1892), Clymene Dolphin Stenella clymene (Gray, 1846), and Harbour Porpoise Phocoena phocoena (Linnaeus, 1758) as potentially occurring in Cape Verde seas. Of these, $S$. teuszii and $E$. glacialis seem rather unlikely candidates because of the former's exclusively coastal habits and marked preference for shallow waters and the latter's great rarity at these latitudes (see also Appendix 2). While $P$. phocoena has been recorded as far south as Mauritania and Senegal (Smeenk et al., 1992), throughout its range it is limited to the waters of the continental shelf (Read, 1999) and its occurrence in the deep Cape Verdean seas seems unlikely. Equally, alleged records of $P$. phocoena from the Azores are now considered dubious (Reiner et al., 1993). Other taxa recorded in adjacent parts of the eastern Atlantic and potentially occurring in Cape Verde seas include Blainville's Beaked Whale Mesoplodon densirostris (De Blainville, 1817), True's Beaked Whale $M$. mirus True, 1913, False Killer Whale Pseudorca crassidens (Owen, 1846), and Fraser's Dolphin Lagenodelphis hosei Fraser, 1956 (cf. Vonk \& Martin Martel, 1988; Jefferson et al., 1997).

Although for some taxa there is now a substantial number of observations, we want to emphasize that all reports of cetaceans from the region remain equally important. Knowledge of spatial and temporal distribution as well as the numbers involved is still rudimentary and only continued reporting can improve this. The collection of data on strandings is hampered by the absence of local naturalists in the Cape Verde Islands, making it virtually impossible to establish a network of correspondents like those operating in other countries. There being no local university or other institutions that could coordinate and stimulate whale and dolphin studies, it is not to be expected that this situation will improve in the foreseeable future. For the time being, progress in knowledge of the Cetacea of the Cape Verde archipelago will have to come from the efforts of visiting researchers. Reports of sightings and strandings (both old and new) from the Cape Verde region $\left(14^{\circ} 00^{\prime} \mathrm{N}-18^{\circ} 00^{\prime} \mathrm{N}\right.$, $22^{\circ} 00^{\prime} \mathrm{W}-26^{\circ} 00^{\prime} \mathrm{W}$ ) will be gratefully received by the authors. Photographic evidence, newspaper items relating to strandings, etc. will also be welcomed, as will information on specimens not included in Appendix 1. All data will be filed in the Cape Verde Cetacean Archive kept at the Museu Bocage, Lisbon, Portugal. It is hoped that this will enable us to present regular updates on the status and occurrence of whales and dolphins in the Cape Verde Islands

\section{Acknowledgements}

We wish to thank C.J. Camphuysen, Steve Madge, Kevin Morgan, Manuela Nunes, Carlos Santos, James Soares, and W. Williams for informing us about their observations of Cetacea in Cape Verde. We also thank the fishermen (not all known by name to us) from the islands of Sal and Boavista for communicating their observations to us. The contributions of our collaborators in the Humpback surveys in 1995 (Melissa Alexander, Sandrine Guittard, and Sue Ryan) and 1996 (Rebecca Clark and Drasko Holcer) have been indispensable. We want to thank P.J.H, van Bree, C.J. Camphuysen, T.A. Jefferson, J.G. Mead, W.F. Perrìn, D.W. Rice, R.C. Sabin, C. Smeenk, and K.C.C. Van Waerebeek for answering queries during the preparation of this paper. W.F. Perrin and K.C.C. Van Waerebeek also commented on a draft version. José Maria Semedo helped in recovering photographs from Cape Verde archives and Peter Stevick informed us about resightings of Humpback Whales between Norway and the West Indies. FWW received equipment and financial support from Allied Whale (U.S.A.), Center for Coastal Studies (U.S.A.), Cetacean Society International (U.S.A.), Mrs. Mary PrattHauvermale (U.S.A.), and the Whale and Dolphin Conservation Society (U.K.). CJH acknowledges a grant from the Netherlands" Ministry of Agriculture, Nature Management and Fisheries (Division of International Affairs). 


\section{References}

Atwood NE. 1887. Whale fishery of Provincetown. In: Goode $\mathrm{GD}$, ed. The fisheries and fishery industries of the United States 2: 144-145. Washington, D.C.x Government Printing Office.

Baker CS, Palumbi SR. 1997. The genetic structure of whale populations: împlications for management. In: Dizon AE, Chivers SJ, Perrin WF, eds. Molecular genetics of marine mammals. Society for Marine Mammalogy, Special Publ. 3: 117-146.

Baker CS, Palumbi SR, Lambertsen RH, Weinrich MT, Calambokidis J, O'Brien SJ. 1990. Influence of seasonal migration on geographic distribution of mitochiondrial DNA haplotypes in humpback whales. Nature 344: 238240 .

Baker CS, Perry A, Bannister JL, Weinrich MT, Abernethy RB, Calambokidis J, Lien J, Lambertsen RH, Urbán Ramírez J, Vasquez O, Clapham PJ, Alling A, O'Brien SJ, Palumbi SR. 1993. Abundant mitochondrial DNA variation and world-wide population structure in humpback whales. Proc. natl. Acad. Sci. U.S.A. 90; 8239-8243.

Baker CS, Slade RW, Bannister JL, Abernethy RB, Weinrich MT, Lien J, Urban J, Corkeron P, Calam: bokidis J, Vasquez O, Palumbi SR. 1994. Hierarchical structure of mitochondrial DNA gene flow among humpback whales Megaptera novaeangliae, world-wide. $\mathrm{Mol}$. Ecol. 3: 313-327.

Bannister JL, Mitchell ED, Balcomb KC. 1984. Report of the subgroup on North Atlantic Humpback boundaries. Rep. int. whaling Comm. 34: 181.

Bree PJH van. 1971. On the taxonomic status of Delphinus pernettensìs de Blainville, 1817 (Notes on Cetacea, Delphinoidea II) . Beaufortia 19: 21-25.

Broekema JW. 1983. Catalogue of Cetacea in the collection of the Rijksmuseum van Natuurlijke Historie, Leiden. ZooL. Meded. (Leiden) 57: 67-69.

Cadenat J. 1959. Rapport sur les petíts Cétacés Ouestafricains. Bull. Inst. fr. Afr. noire (A) 21: 1367-1409, pls. I-XXXI.

Cardoso J. 1896. Pescadores e pescarias no archípelago de Cabo-Verde. Ann. Sci. nat. (Porto) 3: 93-96, 211-216.

Carreira A. 1983. Migraçốes nas ilhas de Cabo Verde. Praía: Instituto Caboverdeano do Livro.

Carreira A. 1986. Ensaio e memórias económicas sobre as Ilhas de Cabo Verde (século XVIII) por João da Silva Feijố. Praia: Instituto Caboverdeano do Livro.

Carrillo M, Jann B, Seton R, Wenzel F. 1999. Present status of Humpback Whales in the Cape Verde Islands. Abstracts 13th Biennial Conference of the Society for Marine Mammalogy, Maul, Hawail, 29 November-4 December 1999.

Chelmickì JCC de, Varnhagen FA de. 1841. Corografia cabo-verdiana ou descripção geográphico-histórica da provincia das ilhas de Cabo-Verde e Guiné. 2 vols. Lisbon: L.C. da Cunha.
Christensen I. 1984. A review of Humpback Whale (Megaptera novaeangliae) observations in the eastern North Atlantic. International Whaling Commission, Scientific Committee, Document SC/36/PS10. 13 pp.

EJM. 1864. Whaling at the Cape de Verdes. Once a Week (London) 11 (267): 194-196.

Ellis M. 1969. A baleia no Brasil colonial. São Paulo: Edições Melhoramentos.

Fournier ' $M$ '. 1847. Des productions et 'du commerce des îles du Cap-Vert, en 1846. Annales Maritimes et Coloniales (3) 3 (Partie non officielle, Section II: Revue Coloniale): 168-174.

Friedlaender I. 1913. Beĭträge zur Kenntnis der Kapverdischen Inseln. Berlinx Dietrich Reimer.

Gray JE. 1866. Description of three species of dolphins in the Free Museum at Liverpool. Proc. Zool. Soc. Lond. 1865: 735-739.

Haase BJM. 1987. A group of Goose-beaked Whales Ziphius cavirostris G. Cuvier, 1823 near the Cape Verde Islands. Lutra 30: 107-108.

Hazevoet CJ. 1999. Whales and dolphins (Mammalia, Cetacea) in the collections of the Museu Bocage, past and present. Arq. Müs. Bocage (Nova Série) 3: 337-354.

Heyning JE, Perrin WF. 1994. Evidence of two species of common dolphins (genus Delphinus) from the eastern north Pacific. Nat. Hist. Mus. Los Angeles County Contr. Sci. 442: 1-35.

Jefferson TA, Curry BE, Leatherwood S, Powell JA. 1997. Dolphins and porpoises of West Africa: a review of records (Cetacea: Delphinidae, Phocoenidae), Mammalia 61: 87108.

Jefferson TA, Leatherwood S, Webber MA. 1993. Marine mammals of the world. FAO species identification guide. Romex United Nations Environment Programme \& Food and Agriculture Organization of the United Nations.

Katona SK, Beard JA. 1990. Population size, migrations and feeding aggregations of the humpback whale (Megaptera novaeangliae) in the western North Atlantic Ocean. Rep. int. whaling Comm. (Special Issue) 12: 295-305.

Kellogg R. 1929. What is known of the migrations of some of the whalebone whales. Smithson. Inst. annu. Rep. 1928: 467-494.

Kirpichnikov AA. 1950. Observations on the distribution of large cetaceans in the Atlantic Ocean. Priroda 10: 6364 [in Russian].

Klinowska M. 1991. Dolphins, porpoises and whales of the world. The IUCN Red Data Book. Gland: International Union for Conservation of Nature and Natural Resources.

Lagendijk P. 1984. Report of a study of the present status of humpback whales around the Cape Verde Islands, March 1984. International Whaling Commission, Scientific Committee, Document SC/36/PS16. 8 pp.

LeDuc RG, Perrín WF, Dizon AE. 1999. Phylogenetic relationships among the delphinid cetaceans based on full cytochrome b sequences. Mar. Mamm. Sci. 15: 619-648.

Lopes J. 1929. Arquipélago de Cabo Verde. Bol. Agência Geral Colon. (Lisbon) 45: 201-214. 
Lopes de Lima JJ. 1844. Ensalo sobre a statistica das ilhas de Cabo-Verde no mar Atlântico e suas dependências na Guiné portugueza ao norte do equador. 2 vols. Lísbon: Imprensa Nacional.

Martin V, Montero R, Heimlich-Boran J, Heimlich-Boran S. 1992. Preliminary observations of the cetacean fauna of the Canary Islands. Eur. Res. Cetaceans 6: 6I-65.

Mittchell E, Reeves RR. 1983. Catch history, abundance and present status of Northwest Atlantic Humpback Whales. Rep. int. whaling Comm. (Special Issue) 5: 153-212.

Miyazaki N, Perrin WF. 1994. Rough-toothed Dolphin Steno bredanensis (Lesson, 1828). In: Ridgway SH, Harrison R, eds. Handbook of Marine Mammals 5: 1-21. London: Academic Press.

Nores C, Pérez C. 1988. Overlapping range between Globicephala macrorhynchus and Globicephala melaena in the northeastern Atlantic. Mammalia 52: 51-55.

Palshøll PJ, Allen J, Bérubé M, Clapham PJ, Feddersen TP, Hammond PS, Hudson RR, Jørgensen H, Katona S, Holm Larsen A, Larsen F, Líen J, Mattila DK, Sigurjonsson J, Sears R, Smith T, Sponer R, Stevick P, Øien N. 1997. Genetic tagging of humpback whales. Nature 388: 767-769.

Payne R, Katona S. 1986. A review of recent evidence affecting stock definitions for Humpback Whales (Megaptera novaeangliae). International Whaling Commission, Scientific Committee, Document SC/38/PS11. 8 pp.

Perrin WF, Mitchell ED, Mead JG, Caldwell DK, van Bree PJII. 1981. Stenella clymene, a rediscovered tropical dolphin of the Atlantic. J. Mamm. 62: 583-598.

Perrin WF, Mitchell ED, Mead JG, Caldwell DK, Caldwell MC, van Bree PJH, Dawbin WH. 1987. Revision of the spotted dolphins, Stenella spp. Mar. Mamm. Sci. 3: 99170.

Perrin WF, Wilson CE, Archer FI. 1994. Striped Dolphin Stenella coeruleoalba (Meyen, 1833). In: Rídgway SH, Harrison R, eds. Handbook of Marine Mammals 5: 129 . 159. London: Academic Press.

Read AJ. 1999. Harbour Porpoíse Phocoena phocoena (Linnaeus, 1758), In: Ridgway SH, Harrison R, eds. Handbook of Marine Mammals 6: 323-355. London: Academic Press.

Reeves RR, Mitchell E. 1988. Kíller whale sightings and takes by American pelagic whalers in the North Atlantic. Rit Fiskidelldar 11: 7-23.

Reiner F, Gonçalves JM, Santos RS. 1993. Two new records of Ziphiidae (Cetacea) for the Azores with an updated checklist of cetacean species. Arquipélago (Ser. Life and Mar. Sci.) 11A: 113-118.

Reiner F, dos Santos ME, Wenzel FW. 1996, Cetaceans of the Cape Verde archipelago. Mar. Mamm. Sci. 12: 434443.
Rice DW. 1998. Marine mammals of the world - systematics and distribution. Society for Marine Mammalogy, Special Publ. 4: 1-231.

Rosel PE, Dizon AE, Heyning JE. 1994. Genetic analysís of sympatric morphotypes of common dolphins (genus Delphinus). Mar. Bíol. 119: 159-167.

Ruud JT. 1937. Bottlenosen Hyperoodon rostratus (Müller). Norsk Hvalfangst-Tidende 26: 456-458.

Slijper EJ, van Utrecht WL, Naaktgeboren C. 1964. Remarks on the distribution and migration of whales, based on observations from Netherlands ships. Bijdr. Dierk. 34: 1-93.

Smeenk C, Leopold MF, Addink MJ. 1992. Note on the harbour porpoíse Phocoena phocoena in Mauritania, West Africa. Lutra 35: 98-104.

Smith TD, Allen J, Clapham PJ, Hammond PS, Katona S, Larsen F, Lien J, Mattila D, Palsbøll PJ, Sigurjónsson J, Stevick PT, Øien N. 1999. An ocean-basin-wide markrecapture study of the North Atlantic Humpback Whale (Megaptera novaeangliae). Mar. Mamm. Sci. 15: 1-32.

Stevick PT, Øien N, Mattila DK. 1998. Migration of a Humpback Whale (Megaptera novaeangliae) between Norway and the West Indies. Mar. Mamm. Sci. 14: 162-166.

Townsend CH. 1935. The distribution of certain whales as shown by logbook records of American whaleships. Zoologica 19: 1-50.

Valsecchi E, Palsbøll P, Hale P, Glockner-Ferrari D, Ferrari $M$, Clapham P, Larsen $F$, Mattila $D$, Sears $R$, Sigurjónsson J, Brown M, Corkeron P, Amos B. 1997. Microsatellite genetic distances between oceanic populations of the Humpback Whale (Megaptera novaeangliae). Mol. Biol. Evol. 14: 355-362.

Vonk R, Martin Martel V. 1988. First list of Odontocetes from the Canary Islands, 1980-1987. Eur. Res. Cetaceans 2: 31-35.

Wilson CE, Perrin WF, Gilpatrick JW, Leatherwood S. 1987. Summary of worldwide locality records of the striped dolphin, Stenella coeruleoalba. NOAA Techn. Memo. NMFS-SWFC-90, La Jolla, California: National Marine Fisheries Service, Southwest Fisheries Science Center.

Winn HE, Reíchley NE. 1985. Humpback Whale Megaptera novaeangliae (Borowski, 1781). In: Ridgway SH, Harrison R, eds. Handbook of Marine Mammals 3: 241-273 London: Academic Press.

Winn HE, Thompson TJ, Cummings WC, Hain J, Hudnall J, Hays H, Steiner WW. 1981. Song of the Humpback Whale: population comparisons. Behav. Ecol. Sociobiol. 8: $41-46$.

Received: 10 November 1999 


\section{Appendix 1}

Cetacea recorded in the Capé Verde region $\left(14^{\circ} 00^{\circ} \mathrm{N}-18^{\circ} 00^{\circ} \mathrm{N}\right.$, $22^{\circ} 00^{\circ} \mathrm{W}-26^{\circ} 00^{\prime} \mathrm{W}$ ). Only taxa the occurrence of which is supported by substantial evidence (specimen, photograph, conclusive description) are included. Sources: 1 - Townsend (1935); 2 - Cadenat (1959); 3 - Lagendijk (1984); 4 - Haase (1987); 5 - Perrin et al, (1987); 6 - Reiner et al. (1996); 7 Hazevoet \& Wenzel (this paper). Museum acronyms: MBL Museu e Laboratório Zoológico e Antropológica (Museu Bocage), Lisboa, Portugal; MNHN - Muséum national d'Hístoíre naturelle, Paris, France; ZMA - Zoőlogisch Museum, Amsterdam, the Netherlands.

\begin{tabular}{lll}
\hline Taxon & Source & Specimen \\
\hline Balaenoptera musculus & 6 & \\
Balaenoptera cf. borealis & 7 & \\
Balaenoptera edeni & 7 & \\
Megaptera novaeangliae & $1,6,7$ & \\
Physeter macrocephalus & $1,6,7$ & \\
Ziphius cavirostris & 4 & \\
Peponocephala electra & 6 & MBL 22.175 \\
Orcinus orca & 7 & \\
Grampus griseus & 6,7 & \\
Globicephala melas & 3,7 & \\
Globicephala macrorhynchus & $3,6,7$ & \\
Steno bredanensis & 7 & \\
Delphinus delphis/capensis & $3,6,7$ & \\
Tursiops truncatus & $3,6,7$ & \\
Stenella attenuata & $2,5,7$ & ZMA 22.962 \\
Stenella frontalis & $3,5,6,7$ & MNHN A-3034, \\
& & A-3035 \\
Stenella coeruleoalba & 7 & \\
Stenella longirostris & 6,7 & \\
\hline
\end{tabular}

\section{Appendix 2.}

Unsubstantiated reports of cetaceans from the Cape Verde region $\left(14^{\circ} 00^{\prime} \mathrm{N}-18^{\circ} 00^{\prime} \mathrm{N}, 22^{\circ} 00^{\prime} \mathrm{W}-26^{\circ} 00^{\prime} \mathrm{W}\right)$. These reports were not supported by any documentation confirming the identity of the taxa discussed.

Slijper et al. (1964) charted five sìghtings of Northern Right Whales Eubalaena glacialis between $10^{\circ} \mathrm{N}-20^{\circ} \mathrm{N}$ and $20^{\circ} \mathrm{W}-30^{\circ} \mathrm{W}$ obtained during the 1950s and mentioned the sighting of a herd of 22 Northern Right Whales with a calf in August (no year given) between $10^{\circ} \mathrm{N}$ and $20^{\circ} \mathrm{N}$ "near the Cape Verde Islands". As no details on identification nor precise dates were given, these reports are considered unsubstantiated. Apart from the great rarity of the taxon in the eastern Atlantic in general and at these latitudes in particular, there is no evidence for the historical occurrence of right whales in the Cape Verde region.

Apart from the record of Balaenoptera of, borealis misidentified as Fin Whale $B$. physalus discussed in the Systematic List above, Reiner et al. (1996) also listed a sighting of two individuals of $B$. physalus. As no details on ídentification were given, we consider this report to be unconfirmed. No documented records of Fin Whale from the Cape Verde region are known to us.

Ruud (1937) stated that the Northern Bottlenose Whale Hyperoodon ampullatus has been seen as far south as the Cape Verde Islands, without giving a source for this assertion. Equally, a listing of the taxon for the Cape Verde region by Martin et al. (1992) was not supported by any evidence. We are not aware of any documented records from Cape Verde seas. In fact, there appear to be no reports of the Northern Bottlenose Whale from the East Atlantic south of the Azores and the Mediterranean (J.G. Mead in litt., 1999).

Listings for the Cape Verde Islands of the Dwarf Sperm Whale Kogia simus (Martin et al, 1992) and Pigmy Killer Whale Feresa attenuata (Martin et al., 1992; Jefferson et al., 1997) were not supported by any evidence and should be disregarded. 